\title{
NÁPOLES: ABRIL DE 1909
}

\section{ARRUGA $A^{1}$}

Sólo hacía diez meses que se había licenciado Hermenegildo Arruga cuando, provisto de una voluminosa cámara - siempre tuvo pasión por la fotografía-, acudió a Nápoles para aprender en el XI Congreso Internacional. Y allí conoció $-\mathrm{y}$ fotografió- a dos colosos de la oftalmología, sin duda los que más hicieron para sacarla de una época de oscurantismo y elevarla a lo más grande en unos años, un avance jamás igualado en otra época. No por nada, unos años más tarde, dijo Victor Morax, refiriéndose a la influencia de Leoz y Balbuena: «Avant, l'ophtalmologie espagnole n'était qu'un mythe de rien du tout. Aujourd'hui ell résonne et tonne comme sur un Sinaï!».

En la fotografía, don Galo Leoz está apoyado en la columna; a su izquierda, con sombrero flexible oscuro, don Félix Fernández Balbuena.

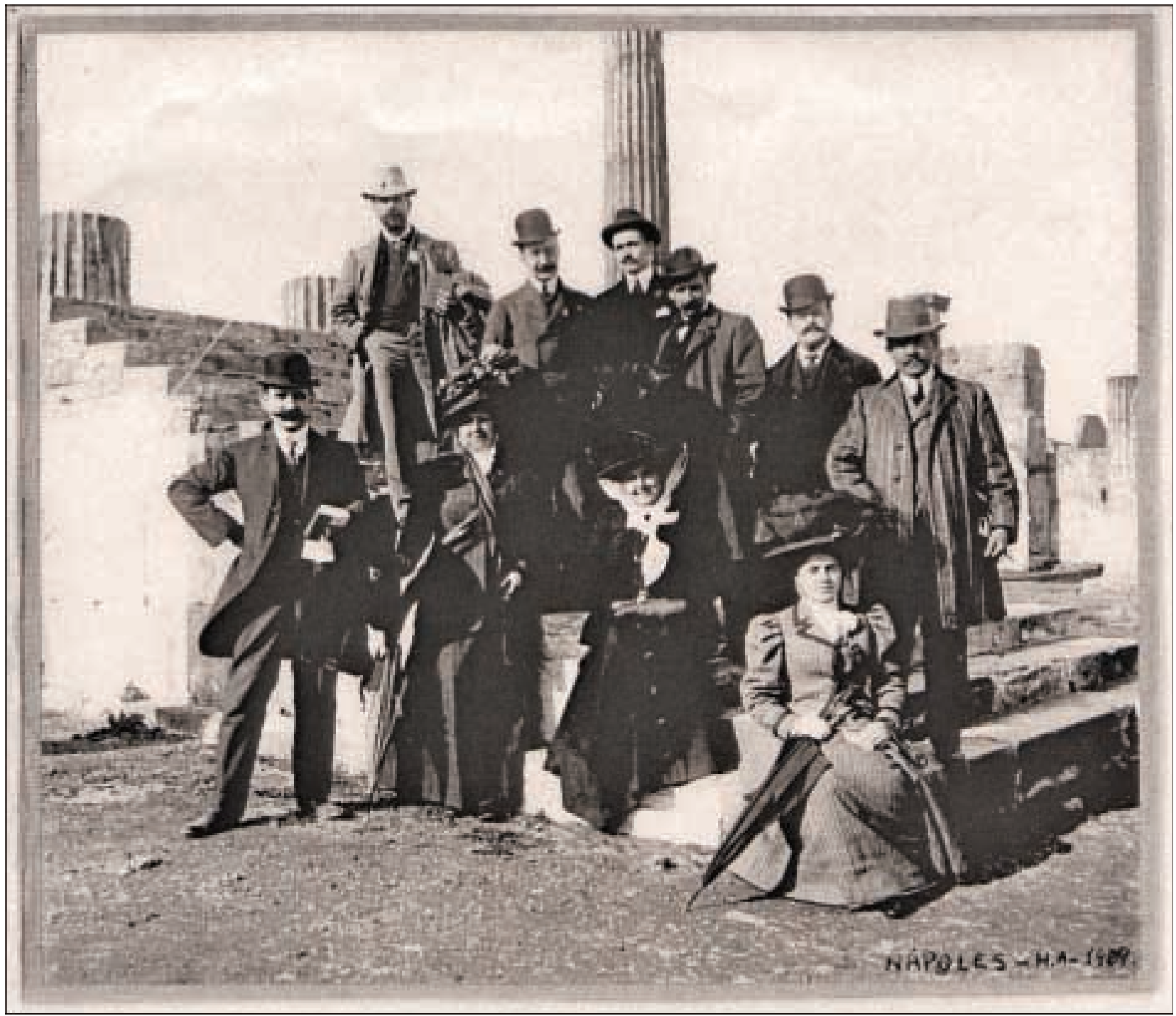

${ }^{1}$ Oftalmólogo. Sant Just Desvern. España.

E-mail: alberto_ac20@hotmail.com. 